\title{
Coeliac Disease
}

\section{Reappraisal of Clinical Diagnosis}

\author{
D. M. COOK, N. EVANS, ANNE LLOYD, and J. S. STEWART \\ From the Departments of Paediatrics and Medicine, West Middlesex Hospital
}

Cook, D. M., Evans, N., Lloyd, A., and Stewart, J. S. (1971). Archives of Disease in Childhood, 46, 705. Coeliac disease: reappraisal of clinical diagnosis. Twelve children previously diagnosed as having coeliac disease on criteria now regarded as incomplete have been reinvestigated. Six were found to have an intestinal mucosal lesion characteristic of coeliac disease. All but one had been asymptomatic on a normal diet for more than 18 months. Response to diet fails to distinguish between coeliacs and non-coeliacs. Establishing the diagnosis of coeliac disease by intestinal biopsy is essential, since even apparently symptomless individuals are at considerable risk.

It is now evident from follow-up studies of childhood coeliac disease that the mucosal abnormality persists if gluten remains in the diet and that relapse is common in early adult life (Mortimer et al., 1968). This paper presents the results of reinvestigating a group of children previously suspected of having coeliac disease.

\section{Material and Methods}

Twelve children at the West Middlesex and Ashford Hospitals, diagnosed between 1959 and 1969 as having coeliac disease, were studied haematologically, radiologically, and by intestinal biopsy. The original diagnosis had been made on clinical grounds in most instances, though fat excretion had been investigated in some patients. Intestinal biopsies had not been performed. All the children had been treated with gluten restriction for at least 6 months. At the time of the present study they had all been on normal diets for over a year with the exception of one (Case 6) who had had a normal diet for only one month.

Haematological methods were those of Dacie and Lewis (1970). Serum folate concentrations were measured by the method of Waters and Mollin (1961). The unequivocally normal range is from 6 to $21 \mathrm{ng} / \mathrm{ml}$; patients with megaloblastic anaemia due to folate deficiency have levels of less than $3 \mathrm{ng} / \mathrm{ml}$. Red cell folate concentrations were obtained by the method of Hoffbrand, Newcombe, and Mollin (1966). The range in control subjects is from 160 to $640 \mathrm{ng} / \mathrm{ml}$ packed red cells.

Barium meals were interpreted using the criteria of Haworth et al. $(1967 ; 1968)$ which these authors

Received 16 April 1971. modified for use in children from the methods described for adults by Laws et al. (1963).

Mucosal biopsies of the proximal small bowel were performed with a Crosby intestinal biopsy capsule (Crosby and Kugler, 1957) modified for use in children and guided through the pylorus with the help of an outer cuff which simplified and shortened the procedure (Evans et al., 1970). All specimens were first examined using a dissecting microscope (Holmes, Hourihane, and Booth, 1961) and subsequently studied histologically (Stewart et al., 1967). The measurements of epithelial surface cell height were made by one of us without knowledge of the clinical history. The normal range of proximal surface cell height is from $29 \cdot 3 \mu$ to $36 \cdot 8 \mu$.

The diagnosis of coeliac disease was considered confirmed if a flat, flat with mosaic, or convoluted proximal intestinal mucosa was found, which showed reduced surface cell height histologically.

\section{Results}

The Table summarizes the results. Only 6 of the 12 patients were found to have coeliac disease.

Clinical features. Symptoms had begun before the end of the second year of life in all but 2 of the coeliac children. These 2 (Cases 4 and 6 ) presented in their third year. Weight loss and diarrhoea were the most common presenting features, and were more marked in the children subsequently shown to have coeliac disease. With the exception of one child (Case 2) all had a good initial response to gluten withdrawal. Subsequently a normal diet had been introduced without 
TABLE

Results

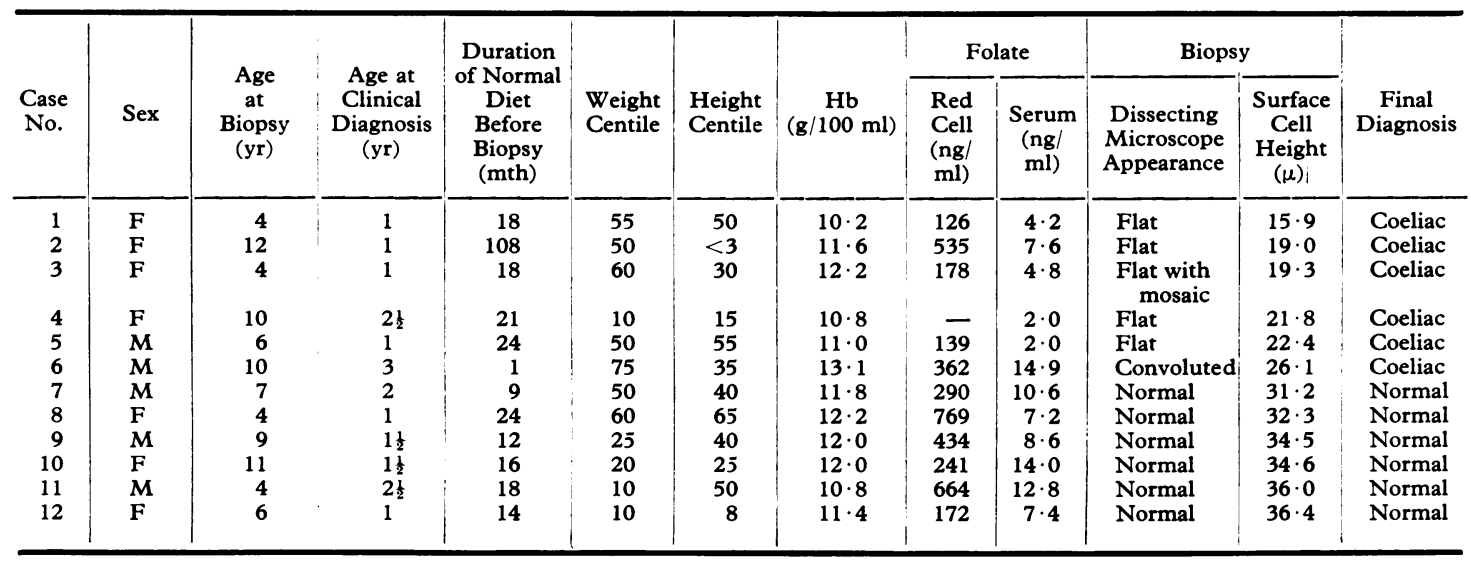

clinical relapse in 11 of the 12 cases, only one (Case 6) having been unable to tolerate gluten.

Physical examination showed no significant abnormalities and measurements of height and weight were not found helpful in separating the coeliac children from those with normal intestinal mucosa.

Haematological and radiological investigations. 2 of the 6 patients with coeliac disease (Cases 1 and 4) had a low $\mathrm{Hb}(>11 \mathrm{~g} / 100 \mathrm{ml}$ ), though only one of these (Case 1) showed hypochromia.

The red cell folate and the serum folate were normal in all 6 non-coeliac patients. The red cell folate was also normal in 2 of the patients with coeliac disease. One of these (Case 2) has been previously reported (Cook et al., 1970). The other (Case 6) had been on a gluten-containing diet for only one month. The serum folate was unequivocally abnormal in only 2 patients with coeliac disease (Cases 4 and 5) but was in the borderline range in 2 others (Cases 1 and 3).

Barium follow-through examination of the small intestine showed that 4 of the 6 coeliac children had dilatation of the small gut and thick mucosal folds.

Intestinal biopsies. Dissecting microscope examination showed a completely flat mucosa in 4 of the 6 coeliac children and in 1 (Case 4) the mucosa was flat with a mosaic pattern. The one biopsy to show a convoluted mucosa, corresponding to moderately severe 'partial villous atrophy', was obtained from the child (Case 6) who was unable to tolerate a normal diet for more than one month. Similarly, this child's epithelial surface cell height $(26 \cdot 1 \mu)$ was the only one from the coeliac children that approached the normal range $(29 \cdot 3$ to $36 \cdot 8 \mu)$.

\section{Discussion}

Our results show that coeliac disease cannot be diagnosed on clinical grounds, nor by a response to gluten restriction. 6 children who had previously been diagnosed as having coeliac disease showed no histological evidence of the disease; haematological, biochemical, and radiological findings were also normal. Gluten restriction in these children had therefore been unnecessary. McNeish (1968) reviewed 23 children diagnosed as having coeliac disease on inadequate criteria, of whom 6 proved to have normal mucosa. However, all his patients had continued with a gluten-free diet until just before the biopsy. 5 of the 6 coeliac children in our study had been free of symptoms on a normal diet for periods between 18 months and 9 years. These children had been considered normal, since they had not relapsed on reintroduction of gluten to the diet.

As it has been shown that the mucosal changes in coeliac disease persist into adult life (Mortimer et al., 1968), children with this disease should continue with their gluten-free diet indefinitely. Complications resulting from inadequately treated coeliac disease are widely recognized. Iron and folate malabsorption in untreated coeliac disease may cause hypochromic and macrocytic anaemias (Dormandy, Waters, and Mollin, 1963; Stewart, 1968; Kilpatrick and Katz, 1969). Folate deficiency secondary to unrecognized coeliac disease 
may be responsible for megaloblastic anaemia of pregnancy (Giles, 1966; Whitfield and Love, 1968). Folate deficiency in pregnancy may be associated with an increased incidence of fetal abnormality (Hibbard and Smithells, 1965); it may also be responsible for some cases of abruptio placentae (Hibbard and Hibbard, 1963) and for recurrent abortions (Martin, Harper, and Kelso, 1965). Morris, Adjukiewicz, and Read (1970) described 3 women with untreated coeliac disease who were infertile until treated with gluten restriction. The aetiology of the infertility in these cases remains obscure, though it may be related to folate deficiency.

Lack of growth is a further potential hazard of untreated coeliac disease. Hamilton, Lynch, and Reilly (1969) showed that $36 \%$ of newly diagnosed children with coeliac disease lay below the 3rd centile for height and $62 \%$ below the 3rd centile for weight. Sheldon (1969), however, found only 6 of his 57 follow-up patients treated during childhood were dwarfed in adult life.

An increased incidence of malignant lymphoma and carcinoma of the gastrointestinal tract has been reported in adults with untreated coeliac disease (Gough, Read, and Naish, 1962; Harris et al., 1967; Wright and Richardson, 1967). There is suggestive evidence that a gluten-free diet may decrease the risk of developing malignancy (Harris et al., 1967). McNeish and Willoughby (1969) have claimed that a normal whole blood folate may be used with confidence to exclude the diagnosis of coeliac disease, but we have not been able to confirm this. In our view no single haematological, biochemical, or radiological test can take the place of an intestinal biopsy. Nevertheless, in an ill, emaciated baby, it may be wiser to postpone the biopsy and to make a provisional diagnosis from indirect investigations. Sufficient evidence may be obtained from the clinical features, red cell folate, faecal fat excretion, and radiological abnormalities to justify treatment with nutritional supplements such as iron, folic acid, or calcium and vitamin $\mathrm{D}$, and even with a glutenfree diet until the child's nutrition has improved. A biopsy examination must be carried out at a later date, and as little as one month on a glutencontaining diet may be sufficient to cause diagnostic abnormalities of the mucosa as in our Case 6.

The absence of symptoms in a child previously suspected of having coeliac disease, but now on a normal diet, does not exclude the diagnosis. We suggest that these children require further investigation and, if the biopsy shows a coeliac mucosal lesion, treatment with a gluten-free diet.

We thank Dr. A. Knudsen's Department of Morbid
Anatomy for the preparation of the intestinal biopsies and the routine histological reports, Dr. F. M. Low for the radiological investigations, Dr. P. D. Roberts for haematological results and advice, and Dr. A. V. Hoffbrand, in Professor J. V. Dacie's Department of Haematology, Royal Postgraduate Medical School, for the estimations of serum and red cell folate.

\section{REFERENCES}

Cook, D. M., Evans, N., Lloyd, A., and Stewart, J. S. (1970). Normal serum and red-cell folate levels in a child with coeliac disease. Lancet, 1, 571.

Crosby, W. H., and Kugler, H. W. (1957). Intraluminal biopsy of the small intestine: the intestinal biopsy capsule. American Fournal of Digestive Diseases, 2, 236.

Dacie, J. V., and Lewis, S. M. (1970). Practical Haematology, 4th ed., Chap. 2 and 3. Churchill, London.

Dormandy, K. M., Waters, A. H., and Mollin, D. L. (1963). Folicacid deficiency in coeliac disease. Lancet, 1, 632.

Evans, N., Farrow, L. J., Harding, A., and Stewart, J. S. (1970). New techniques for speeding small intestinal biopsy. Gut, $11,88$.

Giles, C. (1966). An account of 335 cases of megaloblastic anaemia of pregnancy and the puerperium. Fournal of Clinical Patho$\log y, 19,1$.

Gough, K. R., Read, A. E., and Naish, J. M. (1962). Intestinal reticulosis as a complication of idiopathic steatorrhoea. Gut, 3, 232.

Hamilton, J. R., Lynch, M. J., and Reilly, B. J. (1969). Active coeliac disease in childhood. Quarterly fournal of Medicine, 38, 135.

Harris, O. D., Cooke, W. T., Thompson, H., and Waterhouse, J. A. H. (1967). Malignancy in adult celiac disease and idiopathic steatorrhea. American fournal of Medicine, 42, 899.

Haworth, E. M., Hodson, C. J., Joyce, C. R. B., Pringle, E. M., Solimano, G., and Young, W. F. (1967). Radiological measurement of small bowel calibre in normal subjects according to age. Clinical Radiology, 18, 417.

Haworth, E. M., Hodson, C. J., Pringle, E. M., and Young, W. F. (1968). The value of radiological investigations of the alimentary tract in children with the coeliac syndrome. Clinical Radiology, 19, 65.

Hibbard, B. M., and Hibbard, E. D. (1963). Aetiological factors in abruptio placentae. British Medical fournal, 2, 1430.

Hibbard, E. D., and Smithells, R. W. (1965). Folic acid metabolism and human embryopathy. Lancet, 1, 1245.

Hoffbrand, A. V., Newcombe, B. F. A., and Mollin, D. L. (1966). Method of assay of red cell folate activity and the value of the assay as a test for folate deficiency. Journal of Clinical Patho$\log y, 19,17$.

Holmes, R., Hourihane, D. O'B., and Booth, C. C. (1961). Dissecting-microscope appearances of jejunal biopsy specimens from patients with 'idiopathic steatorrhoea'. Lancet, 1, 81 .

Kilpatrick, Z. M., and Katz, J. (1969). Occult celiac disease as a cause of iron deficiency anemia. Fournal of the American Medical Association, 208, 999.

Laws, J. W., Shawdon, H., Booth, C. C., and Stewart, J. S. (1963). Correlation of radiological and histological findings in idiopathic steatorrhoea. British Medical fournal, 1, 1311.

McNeish, A. S. (1968). Diagnosis of coeliac disease in retrospect. Archives of Disease in Childhood, 43, 362.

McNeish, A. S., and Willoughby, M. L. N. (1969). Whole-blood folate as a screening test for coeliac disease in childhood. Lancet, 1, 442.

Martin, R. H., Harper, T. A., and Kelso, W. (1965). Serum-folicacid in recurrent abortions. Lancet, 1, 670.

Morris, J. S., Adjukiewicz, A. B., and Read, A. E. (1970). Coeliac infertility: an indication for dietary gluten restriction. Lancet, $1,213$.

Mortimer, P. E., Stewart, J. S., Norman, A. P., and Booth, C. C. (1968). Follow-up study of coeliac disease. British Medical fournal, 3, 7.

Sheldon, W. (1969). Prognosis in early adult life of coeliac children treated with a gluten-free diet. British Medical fournal, 2, 401. 
Stewart, J. S. (1968). Adult coeliac disease. Postgraduate Medical fournal, 44, 632.

Stewart, J. S., Pollock, D. J., Hoffbrand, A. V., Mollin, D. L., and Booth, C. C. (1967). A study of proximal and distal intestinal structure and absorptive function in idiopathic steatorrhoea. Quarterly fournal of Medicine, 36, 425.

Waters, A. H., and Mollin, D. L. (1961). Studies on the folic acid activity of human serum. fournal of Clinical Pathology, 14, 335.
Whitfield, C. R., and Love, A. H. G. (1968). Intestinal malabsorption in megaloblastic pregnancy anaemia. Fournal of Obstetrics and Gynaecology of the British Commonwealth, 75, 844.

Wright, J. T., and Richardson, P. C. (1967). Squamous carcinoma of the thoracic oesophagus in malabsorption syndrome. British Medical fournal, 1, 540.

Correspondence to Dr. D. M. Cook, Nottingham Children's Hospital, Chestnut Grove, Nottingham. 